\title{
THE PLACENTAL TRANSFER OF GASES AND FIXED ACIDS
}

\author{
BY \\ G. ROOTH and S. SJÖSTEDT* \\ From the Department of Obstetrics and Gynaecology and the Department of Internal Medicine, \\ University Hospital, Lund, Sweden
}

(RECEIVED FOR PUBLICATION JANUARY 26, 1962)

The possibility of obtaining intervillous blood from pregnant women has made it feasible to study the placental exchange of various substances. Those which are perhaps most vital, i.e. oxygen and carbon dioxide, have already been studied to some extent (Prystowsky, 1957, 1958, 1959, 1960; Prystowsky, Hellegers and Bruns, 1960; Walker, 1959; Sjöstedt, Rooth and Caligara, 1960; Rooth, Sjöstedt and Caligara, 1961b). It is the purpose of the present paper to give a more complete picture of the placental transfer by describing both the transfer of the blood gases and the fixed acids.

\section{Material and Methods}

In 10 cases the intervillous space was punctured not earlier than three days before onset of labour. The technique has been described earlier by Sjöstedt et al. (1960).

In 22 cases measurements were done on cord blood. All were spontaneous vertex deliveries. In 18 cases the infants showed no sign of asphyxia, while in four cases such signs were slightly present. The cord was clamped in two places as soon as it presented itself and before the onset of respiration. The cord was rapidly brought from the delivery room to our laboratory where the blood was drawn into heparinized syringes, and the analyses were immediately initiated. Haemoglobin, oxygen tension $\left(\mathrm{pO}_{2}\right), p \mathrm{H}$, carbon dioxide tension $\left(\mathrm{pCO}_{2}\right)$, buffer base (BB) and base excess (BE) as well as lactic acid were measured in the samples.

Haemoglobin was determined as oxyhaemoglobin (Rooth and Sjöstedt, 1957). $\mathrm{pO}_{2}$ was measured polarographically by a system similar to that described by Rooth, Sjöstedt and Caligara (1959b). However, instead of a lucite cuvette, one of nickel-plated brass was used, which reduced the time for the measurements to 45 seconds. The reliability of the method was as good as before. $p \mathrm{H}$ was measured with a radiometer type $22 p \mathrm{H}$ meter and based on N.B.S. standards. $\mathrm{pCO}_{2}$ was measured according to Severinghaus and Bradley (1958).

The lactic acid was determined by a modification of the

* Present address: Centrallasarettet, Department of Obstetrics and Gynaecology, Linköping, Sweden.
Barker and Summerson (1941) method which only needs $0.1 \mathrm{ml}$. of blood (I. H. Kaiser, personal communication, 1959).

In order to obtain the necessary figures for calculating the intervillous oxygen loss and carbon dioxide and fixed acid transportation, data from two further series were used.

In 16 pregnant women without signs of heart disease, pulmonary disease or toxaemia, arterial oxygen tension was measured with the technique described by us in 1959 (Rooth et al., 1959b). The women were all in the 37 th to 42 nd week of pregnancy. The same analyses were performed on 11 non-pregnant women of the same age group. The arterial punctures were done in the brachial artery with the women sitting.

On another group of 85 pregnant women between the 37th and 43rd week, arterial $p \mathrm{H}, \mathrm{pCO}_{2}, \mathrm{BB}$ and $\mathrm{BE}$ were measured with the Astrup microtechnique using capillary blood (Sjöstedt, 1962).

The oxygen content of whole blood $\left(\mathrm{CO}_{2}\right)$ was obtained from the amount of dissolved oxygen and from the oxygen saturation, which was calculated from the oxygen tension and the $p \mathrm{H}$ using the appropriate oxygen dissociation curves, that of Bartels and Harms (1959) for adult blood and that of Rooth, Sjöstedt and Caligara (1959a) for foetal blood.

The $\mathrm{CO}_{2}$ content of whole blood $\left(\mathrm{cCO}_{2}\right)$ was obtained in the following way: from the diagram of Siggaard Andersen and Engel (1960), the serum bicarbonate content was calculated. To this was added the dissolved $\mathrm{CO}_{2}$ which gave the total serum $\mathrm{CO}_{2}$. With due attention to the necessary corrections for unsaturated haemoglobin, the $\mathrm{CCO}_{2}$ was obtained from the nomograph of Van Slyke and Sendroy (1928).

The discussion on the metabolic acid base balance will be limited to BE as we, in agreement with Astrup, Jørgensen, Siggaard Andersen and Engel (1960), feel that the metabolic acidosis or alkalosis is best expressed in terms of BE which has the advantage of being independent of haemoglobin concentration.

\section{Results}

The mean of the measured or calculated values for $p \mathrm{H}, \mathrm{Hb}, \mathrm{pO}_{2}, \mathrm{pCO}_{2}, \mathrm{cCO}_{2}, \mathrm{BB}, \mathrm{BE}$ and lactic acid in the umbilical vessels and from the intervillous 
TABLE 1

MEAN VALUE $O_{2}$ PRESSURE AND CONTENT, $p \mathrm{H}, \mathrm{CO}_{2}$ PRESSURE AND CONTENT, BUFFER BASE, BASE EXCESS AND LACTIC ACID IN UMBILICAL BLOOD OF FOETUS AND INTERVILLOUS BLOOD OF MOTHER

\begin{tabular}{|c|c|c|c|c|c|c|c|c|c|c|c|}
\hline Cases & & & Number & $\begin{array}{c}\mathrm{pO}_{2} \\
(\mathrm{~mm} . \mathrm{Hg})\end{array}$ & $\underset{(\mathrm{mEq} / \mathrm{l} .)}{\mathrm{CO}_{2}}$ & $p \mathbf{H}$ & $\begin{array}{c}\mathrm{pCO}_{2} \\
(\mathrm{~mm} . \mathrm{Hg})\end{array}$ & $\underset{(\mathrm{mEq} / \mathrm{l} .)}{\mathrm{cCO}_{2}}$ & $\underset{(\mathrm{mEq} / 1 .)}{\text { BB }}$ & $\underset{(\mathrm{mEq} / 1 .)}{\mathbf{B E}}$ & $\begin{array}{l}\text { Lactic Acid } \\
\text { (mEq/1.) }\end{array}$ \\
\hline $\begin{array}{l}\text { Normal } \\
\text { Umbilical artery } \\
\text { Umbilical vein } \\
\text { Intervillous .. }\end{array}$ & $\begin{array}{l}\cdots \\
\cdots\end{array}$ & $\begin{array}{l}. \\
\therefore \\
\therefore\end{array}$ & $\begin{array}{l}18 \\
18 \\
10\end{array}$ & $\begin{array}{l}18 \cdot 0 \\
29 \cdot 5 \\
44 \cdot 5\end{array}$ & $\begin{array}{l}3 \cdot 8 \\
7 \cdot 4 \\
7 \cdot 2\end{array}$ & $\begin{array}{l}7 \cdot 25 \\
7 \cdot 32 \\
7 \cdot 40\end{array}$ & $\begin{array}{l}48 \cdot 8 \\
39 \cdot 6 \\
36 \cdot 5\end{array}$ & $\begin{array}{l}17 \cdot 3 \\
16 \cdot 7 \\
19 \cdot 3\end{array}$ & $\begin{array}{l}38 \cdot 4 \\
41 \cdot 7 \\
44 \cdot 5\end{array}$ & $\begin{array}{l}-9 \cdot 4 \\
-6 \cdot 2 \\
-2 \cdot 2\end{array}$ & $\begin{array}{l}4 \cdot 6 \\
4 \cdot 1 \\
2 \cdot 5\end{array}$ \\
\hline $\begin{array}{l}\text { Asphyxiated } \\
\text { Umbilical artery } \\
\text { Umbilical vein }\end{array}$ & $\begin{array}{l}\cdots \\
\cdots\end{array}$ & $\begin{array}{l}. \\
\cdots\end{array}$ & $\begin{array}{l}4 \\
4\end{array}$ & $\begin{array}{l}17 \cdot 1 \\
22 \cdot 8\end{array}$ & $\begin{array}{l}2 \cdot 6 \\
5 \cdot 2\end{array}$ & $\begin{array}{l}7 \cdot 13 \\
7 \cdot 21\end{array}$ & $\begin{array}{l}54 \cdot 9 \\
43 \cdot 6\end{array}$ & $\begin{array}{l}15 \cdot 0 \\
14 \cdot 4\end{array}$ & $\begin{array}{l}31 \cdot 7 \\
35 \cdot 2\end{array}$ & $\begin{array}{l}-16 \cdot 2 \\
-12 \cdot 7\end{array}$ & $\begin{array}{l}5 \cdot 6 \\
5 \cdot 1\end{array}$ \\
\hline
\end{tabular}

TABLE 2

MEAN AND RANGE OF ARTERIAL OXYGEN TENSION IN PREGNANT AND NON-PREGNANT WOMEN

\begin{tabular}{lll|c|c}
\hline & & Number & $\begin{array}{c}\text { pO }{ }_{2 \mathrm{~s}} \\
(\mathrm{~mm} . \mathrm{Hg})\end{array}$ \\
\hline Pregnant & $\ldots$ & $\ldots$ & 16 & $\begin{array}{c}97 \cdot 1 \\
(88 \cdot 8-109 \cdot 6)\end{array}$ \\
Non-pregnant & $\ldots$ & $\ldots$ & 11 & $\begin{array}{c}94 \cdot 8 \\
(84 \cdot 8-106 \cdot 4)\end{array}$ \\
\hline
\end{tabular}

$\mathbf{M}=$ maternal blood.

TABLE 4

MEAN VALUES OF INDIVIDUAL DIFFERENCES ( 4 ) BETWEEN THE UMBILICAL ARTERY AND VEIN $\mathrm{OF}_{2} \mathrm{O}_{2}$, $\mathrm{O}_{2}$, BE AND TOTAL FIXED ACIDS

\begin{tabular}{|c|c|c|c|c|c|c|}
\hline & & $\begin{array}{l}\text { Number } \\
\text { of Cases }\end{array}$ & $\underset{(\mathrm{mEq} / \mathrm{l} .)}{\mathrm{C} \mathrm{CO}_{2} \mathrm{~F}}$ & $\underset{(\mathrm{mEq} / \mathrm{l} .)}{\Delta \mathrm{BE}_{\mathrm{F}}}$ & $\underset{(\mathrm{mEq} / \mathrm{l} .)}{\Delta \underset{\mathrm{T}}{\mathrm{T}}}$ & $\underset{(\mathrm{mEq} / \mathrm{l} .)}{\Delta \mathrm{O}_{2 \mathrm{~F}}}$ \\
\hline $\begin{array}{l}\text { Normal cases . } \\
\text { Asphyxiated cases }\end{array}$ & $\begin{array}{ll}\cdots & \cdots \\
\cdots & \cdots\end{array}$ & $\begin{array}{r}16 \\
4\end{array}$ & $\begin{array}{l}0.6 \\
0.6\end{array}$ & $\begin{array}{l}3 \cdot 0 \\
3 \cdot 9\end{array}$ & $\begin{array}{l}3 \cdot 6 \\
4 \cdot 5\end{array}$ & $\begin{array}{l}3 \cdot 6 \\
2 \cdot 6\end{array}$ \\
\hline
\end{tabular}

The $\Delta$ figures are the mean of the individual $\Delta$ values and not the difference between the mean values given in Table 1 . $F=$ foetal blood. space is given in Table 1 . The mean arterial $\mathrm{pO}_{2 \mathrm{M}}$ in the pregnant and non-pregnant women is given in Table 2 and the mean values for arterial $p \mathrm{H}_{\mathrm{M}}, \mathrm{pCO}_{2 \mathrm{M}}$ and $\mathrm{BE}_{\mathrm{M}}$ of the pregnant women are given in Table 3. In the following, $\mathrm{pO}_{2 \mathrm{M}}$ means $\mathrm{pO}_{2}$ in the maternal blood, $\mathrm{pO}_{2 \mathrm{~F}}$ means $\mathrm{pO}_{2}$ in the foetal blood, etc.

The mean of the individual differences $(\Delta)$ between the carbon dioxide content of the umbilical artery and vein as well as the corresponding differences $(\Delta)$ for base excess, total acids and total oxygen content are given in Table 4.

\section{Discussion}

The figures here presented make possible a quantitative description of the interrelation between the gas and acid transfer across the placenta. Before this is done it is necessary to discuss the limitations of the measurements and to compare the present figures with those of other authors.

Umbilical Cord Blood and Intervillous Blood. $p \mathrm{H}, \mathrm{pO}_{2}, \mathrm{pCO}_{2}$ and $\mathrm{Hb}$ are essentially the same as
TABLE 3

MEAN AND RANGE OF MATERNAL HYDROGEN ION CONCENTRATION, CARBON DIOXIDE TENSION AND BASE EXCESS

\begin{tabular}{c|c|c|c}
\hline Number & $p \mathrm{H}_{\mathrm{M}}$ & $\begin{array}{c}\mathrm{pCO}_{2 \mathrm{M}} \\
(\mathrm{mm} . \mathrm{Hg})\end{array}$ & $\begin{array}{c}\mathrm{BE}_{\mathrm{M}} \\
(\mathrm{mEq} / 1 .)\end{array}$ \\
\hline 85 & $\begin{array}{c}7 \cdot 463 \\
(7 \cdot 405-7 \cdot 515)\end{array}$ & $\begin{array}{c}30 \cdot 8 \\
(25-37)\end{array}$ & $\begin{array}{c}+0 \cdot 2 \\
(-4 \cdot 5-+4 \cdot 5)\end{array}$ \\
\hline
\end{tabular}

$\mathbf{M}=$ maternal blood in our earlier studies (Sjöstedt et al., 1960; Rooth et al., 1961b) and the reader is referred to these for comparisons of the relevant literature. To these should be added the work by Vasicka, Quilligan, Aznar, Lipsitz and Bloor (1960), who found lower $\mathrm{pO}_{2}$ values in the intervillous space $(33 \mathrm{~mm} . \mathrm{Hg})$ and consequently also in the umbilical vein $(21 \mathrm{~mm}$. $\mathrm{Hg})$ and in the umbilical artery $(10 \mathrm{~mm} . \mathrm{Hg})$. This discrepancy is possibly due to the different treatment of the patient in premedication and anaesthesia. The BE values in the present study are more reliable than those in the earlier publications where $\mathrm{Hb}$ was not measured. The mean of our normal cases is $-6 \cdot 2 \mathrm{mEq} / \mathrm{l}$. in the umbilical vein and $-9 \cdot 4 \mathrm{mEq} / 1$. in the umbilical artery. The difference of the mean is 3.2 as against 3.9 in the earlier study. The difference, however, is not affected by the $\mathrm{Hb}$ levels, and the discrepancy is therefore an indication of the variations in the material and the errors in the measurements.

The fact that metabolic acidosis occurs in the umbilical vessels is well known from Yllpö (1916) 
and several subsequent studies (Österlund, 1955). As these authors only gave figures for $p \mathrm{H}$ and $\mathrm{pCO}_{2}$ or at best for $\mathrm{CO}_{2}$-combining power, their results are not directly comparable with the present material. Only Beer, Bartels and Raczkowski (1955) give sufficient data for a calculation of $B E$. When this is done $\mathrm{BE}$ is found to be -4.8 in the arteries (nine cases) and $-3 \cdot 4$ in the veins (11 cases). This discrepancy may be due to the fact that these authors calculated the $p \mathrm{H}$.

James (1959) finds a mean BB of 39 in the umbilical arteries of vigorous infants (26 cases) and of 37 in mildly depressed infants (six cases). In another series James, Weisbrot, Prince, Holaday and Apgar (1958) find a BB of about 41 in the arteries and almost the same value in the vein. The small arteriovenous difference would indicate no passage of fixed acids. This may be because the means used are obtained from different cases, as it has not been possible to measure BB in blood from the arteries and vein of the same cases except in a few instances. However, these BB levels agree with ours.

According to our figures the lactic acid concentration is highest in the umbilical artery, lower in the vein $\left(\Delta \operatorname{lact}_{F} 0.5 \mathrm{mEq} / \mathrm{l}\right.$., $\left.\mathrm{p}<0.01\right)$ and lower still in the intervillous blood. The studies of lactic acids have been discussed in detail by Vedra (1959). To sum up, our results agree with those of Bell, Cunningham, Jowett, Millet and Brooks (1928), Kaiser and Goodlin (1958) and Hendrichs (1957). Eastman and McLane (1931) and Vedra (1959, 1960) find higher values in the maternal blood than in the foetal blood, but all the authors cited have measured the maternal venous blood and not the intervillous blood. Vedra finds a difference between the umbilical artery and the umbilical vein which is on the $5 \%$ level, but which he doubts. Eastman and McLane (1931) only find a difference between the umbilical vessels in cases of asphyxia.

During labour the mother has a higher lactic acid content than before (Kaiser and Goodlin, 1958), and it is possible that in a non-steady state there is a net passage of lactic acid from the mother to the foetus. Friedman, Gray, Grynfogel, Hutchinson, Kelly and Plentl (1960) studying the rhesus monkey have given interesting information about the transfer of lactic acid between the foetus, the amniotic fluid and the mother. In the amniotic fluid we have found a mean value of $8.5 \mathrm{mEq} / \mathrm{l}$. of lactic acid in eight uncomplicated cases punctured before onset of labour. This is the same level as found by Hendrichs (1957), and the high concentration probably derives from the urine of the foetus (see also Rooth, Sjöstedt and Caligara, 1961a; Sjöstedt, 1962). Their results indicate that regardless of the concentrations there is a continuous interchange of lactic acid between the foetus and the mother.

Arterial Blood of the Mother. We find no significant difference in arterial oxygen tension between non-pregnant and pregnant women. The small difference observed agrees with that of Rossier and Hotz (1953) who measured oxygen saturation. On the basis of the work of Rossier and Hotz (1953), Beer et al. (1955) calculated that the arterial $\mathrm{pO}_{2}$ of the pregnant women was $110 \mathrm{~mm}$. $\mathrm{Hg}$. Our mean value of 97 is the same as that of Vasicka et al. (1960).

The $\mathrm{pCO}_{2}$ of the pregnant woman is known to be low, since the original publication of Hasselbalch (1912). The present figure of $31 \mathrm{~mm}$. $\mathrm{Hg}$ taken on capillary blood agrees with that of Rossier and Hotz who found $33 \mathrm{~mm} . \mathrm{Hg}$ in the brachial artery and Boutouline-Young and Boutouline-Young (1956) who found $30-32 \mathrm{~mm}$. $\mathrm{Hg}$ in the expiratory air.

As the pregnant women have a low $\mathrm{pCO}_{2}$ and a high $p \mathrm{H}$ they have a respiratory alkalosis.

Whether the pregnant woman has a metabolic acidosis or not has been the subject of some discussion. The early literature on this subject is surveyed in detail by Rossier and Hotz (1953) and Österlund (1955). The reduction in the $\mathrm{CO}_{2}$ combining power observed by Darling, Smith, Asmussen and Cohen (1941) has led to the general opinion that there is a metabolic acidosis. The present figures (Sjöstedt, 1962) indicate only a slight metabolic acid-base change.

Effect of Non-simultaneous Measurements and of Analyses on Different Groups of Cases. As complicated deliveries are different and caused by a variety of reasons, it must be extremely hazardous to compare intervillous maternal or foetal umbilical blood from one complicated case with another, but in the case of normal conditions such a comparison should not introduce a major error. It is of greater importance that the intervillous blood samples have always been taken before the onset of labour and the umbilical blood has always been taken after the delivery.

It is likely that were the intervillous blood taken at the time of delivery its lactic acid content would be higher than we have found, but it would hardly be as high as in the umbilical artery. Concomitant with an increased lactic acid content, we would find a lower value for our BE. It would probably be at least $1 \mathrm{mEq} / \mathrm{l}$. lower.

It is also possible that the $\mathrm{pCO}_{2}$ of the intervillous space during delivery is intermittently lower than 
that observed by us because of hyperventilation by the mother. This, however, will hardly be a constant finding.

The oxygen in the intervillous space does not seem to be affected by the delivery. Prystowsky (1959), who has taken his intervillous samples immediately before delivery, gives the same mean $\mathrm{pO}_{2}$ as we have found before the onset of labour. The net effect, if the samples had all been taken at the time of delivery, would be a slight decrease in the $\mathrm{BE}$ of the intervillous blood.

The calculation of the $\Delta \mathrm{O}_{2 \mathrm{M}}$ for the maternal blood is not influenced by the fact that the arterial $\mathrm{pO}_{2 \mathrm{M}}$ was measured on a different group of subjects from the intervillous $\mathrm{pO}_{2 \mathrm{M}}$. A small difference in arterial $\mathrm{pO}_{2 \mathrm{M}}$ would not be noticeable in the results. The $p \mathrm{H}, \mathrm{pCO}_{2}$ and $\mathrm{BE}$ measurement of the arterial blood in the pregnant woman is of more importance. If the intervillous blood has a lower $\mathrm{pCO}_{2 \mathrm{M}}$ during delivery because of hyperventilation, this of course is due to a low arterial $\mathrm{pCO}_{2 \mathrm{M}}$ and the $\Delta \mathrm{CO}_{2 \mathrm{M}}$ would be lower. If the mother has an increased concentration of lactic acid, the $\mathrm{BE}_{\mathrm{M}}$ of the arterial blood will also be lower and the $\mathrm{BE}_{\mathrm{M}}$ will at least not be higher than found.

This discussion of the errors has shown that the analyses of the heterogeneous maternal samples taken at different times is correct as far as oxygen is concerned but is probably somewhat inaccurate as far as $\mathrm{pCO}_{2 \mathrm{M}}, \mathrm{CCO}_{2 \mathrm{M}}$, and $\mathrm{BE}_{\mathrm{M}}$ are concerned. The foetal blood studies which were all done on samples taken at the same time do not have these errors.

A calculation of the total exchange of the foetus gives the values shown in Table 4 . The $\Delta \mathrm{O}_{2 \mathrm{~F}}$ is $3.6 \mathrm{mEq} / \mathrm{l}$. If the foetal placental exchange is not impaired, the total acid excretion should equal this, and we found a mean value of $3.6 \mathrm{mEq} / 1$. of $\Delta \mathrm{CO}_{2 \mathrm{~F}}$ and $\triangle \mathrm{BE}_{\mathrm{F}}$ together. This shows that our normal foetuses have been in a steady state. The four distressed cases all show lower values for oxygen, the acid excretion is normal in three cases and considerably elevated in one case.

The important point in this connexion is that the present study has shown that the figures obtained from cord blood taken immediately after delivery are representative of the intrauterine conditions, as, for reasons given earlier (Sjöstedt et al., 1960; Rooth et al., 1961b), the values cannot be higher for $\mathrm{pCO}_{2 \mathrm{~F}}$ and $p \mathrm{H}_{\mathrm{F}}$ and not lower for $\mathrm{pCO}_{2 \mathrm{~F}}$, and furthermore the balance studies show that the foetuses are in a steady state.

As regards the total acid excretion, the present study gives rise to interesting speculations, but because of the indirect way of measuring the $\mathrm{CO}_{2}$ content, we feel that for the moment not too much attention should be focused on the relative distribution of the components making up the acid excretion. As will be seen in Table 4 , the $\Delta \mathrm{CO}_{2 \mathrm{~F}}$ is only $0.6 \mathrm{mEq} / 1$. In fact, in six of the normal cases and in two of the asphyxiated cases, the $\mathrm{CO}_{2 \mathrm{~F}}$ content was higher in the umbilical vein than in the artery due to the higher $p \mathrm{H}$ and resulting higher $\mathrm{CO}_{2 \mathrm{~F}}$ binding capacity. These results were unexpected, although Vedra (1959) finds a $\Delta$ bicarbonate plasma $_{F}$ of $0.7 \mathrm{mEq} / \mathrm{l}$. which would probably correspond to a $\Delta \mathrm{CO}_{2 \mathrm{~F}}$ of about $0.5 \mathrm{mEq} / \mathrm{l}$. Österlund (1955) also gives a $\Delta$ alkali reserve ${ }_{F}$ of $2.4 \mathrm{mEq} / \mathrm{l}$, which is twice that of Beer et al. (1955) and probably corresponds to a $\triangle \mathrm{BE}$ of $3 \mathrm{mEq} / 1$. These results are opposed to those of, for instance, Haselhorst and Stromberger (1930) and Beer et al. (1955). The latter find a mean $\Delta \mathrm{CO}_{2 \mathrm{~F}}$ of $2 \cdot 8$ $\mathrm{mEq} / \mathrm{l}$. and a $\Delta \mathrm{BE}_{\mathrm{F}}$ of $1 \cdot 4$, i.e. a total $\Delta$ acids of $4.2 \mathrm{mEq} / \mathrm{l}$. Thus, although the total $\Delta$ acids are of the same magnitude, the $\Delta \mathrm{CO}_{2 \mathrm{~F}}$ and $\triangle \mathrm{BE}_{\mathrm{F}}$ differ greatly. This point calls for further investigation because if our figures are correct they give important information about the foetal metabolism. As we obtained the same $\Delta \mathrm{BE}_{\mathrm{F}}$ in both the present study and in our earlier one (Rooth et al., 1961b) it will be necessary to do direct measurements of the $\mathrm{CO}_{2}$ content in future.

In the corresponding maternal balance the $\Delta \mathrm{O}_{2 \mathrm{M}}$ is $1.9 \mathrm{mEq} / \mathrm{l} ., \Delta \mathrm{CO}_{2 \mathrm{M}} 1.5$ and $\Delta \mathrm{BE}_{\mathrm{M}} 2 \cdot 7$. Here we find an R.Q. of 0.8 which seems not unexpected, but the total amount of acid is higher than that of the corresponding amount of oxygen. If instead we were to take for comparison figures for $\mathbf{B E}_{\mathbf{M}}$ from our earlier study (Rooth et al., 1961b) the oxygen and carbon dioxide values would be similar but the $\mathrm{BE}_{\mathrm{M}}$ would be smaller and a balance would be obtained. This shows that the studies have to be done on the same patients, as we have indicated above.

However, as the oxygen figures will not be affected by this error, it is interesting to see what information we get by comparing the maternal and foetal $\mathrm{CO}_{2}$. If we assume that the maternal $\mathrm{CO}_{2 \mathrm{M}}$ is not affected by the oxygen consumption of the uterus itself, the ratio of $\Delta \mathrm{O}_{2 \mathrm{~F}} / \Delta \mathrm{O}_{2 \mathrm{M}}$ equals the ratio of maternal placental blood flow to foetal placental blood flow and is $1 \cdot 8: 1$. Were the magnitude of either the foetal or the maternal blood flow known, the other could then be readily calculated and so too could the foetal oxygen consumption.

The figures available for the human uterine blood flow have been reviewed by Metcalfe, Romney, Swartwout, Pitcairn, Lethin and Barron (1959) and given as $150 \mathrm{ml} . / \mathrm{kg} . / \mathrm{min}$. The foetal blood flow would then be $80 \mathrm{ml} . / \mathrm{kg} . / \mathrm{min}$. In a foetus of 
$3.5 \mathrm{~kg}$. this would correspond to a foetal placental minute volume of $0.3 \mathrm{l}$. The oxygen consumption would be $2 \cdot 4 \mathrm{ml} . / \mathrm{min}$.

As the present study has led to figures for the oxygen consumption and carbon dioxide production of the foetus as well as the magnitude of the foetal versus maternal placental circulation, and also gives some idea as to the metabolism of the foetal tissues, it seems that they should be repeated with as many simultaneously performed analyses as possible. This, however, meets with considerable clinical difficulties.

\section{Summary}

The blood from the umbilical vein and artery has been studied in 18 normal deliveries and in four cases where the infants were mildly asphyxiated.

Figures are given for the oxygen tension, carbon dioxide tension, oxygen content, carbon dioxide content, $p \mathrm{H}$, base excess and lactic acid.

In 10 cases intervillous blood was obtained before delivery and analysed.

The foetus receives $3.6 \mathrm{mEq} / 1$. of oxygen and eliminates $3.6 \mathrm{mEq} / \mathrm{l}$. of total acids.

This balance shows that the foetus, at the time when the samples were taken, i.e. immediately after delivery, was in a steady state. This, together with results drawn from the intervillous measurements, shows that the analyses of cord blood presented by us, here as well as earlier, are representative of the intrauterine conditions during the last period of pregnancy.

The data presented give a physiological picture of the gas exchange levels of the foetus and give figures for the calculation of the ratio between the foetal and maternal placental blood flow. The foetal placental minute volume is about $0 \cdot 3$ litre.

This study has been supported by grants from the Association for the Aid of Crippled Children, New York, U.S.A., and the Swedish Medical Research Council, Uppsala, Sweden.

\section{REFERENCES}

Astrup, P., Jørgensen, K., Siggaard Andersen, O. and Engel, K (1960). The acid-base metabolism. A new approach. Lancet, $1,1035$.

Barker, S. B. and Summerson, W. H. (1941). The colorimetric determination of lactic acid in biological material. J. biol. Chem., 138, 535 .

Bartels, H. and Harms, H. (1959). Sauerstoffdissoziationskurven des Blutes von Säugetieren (Mensch, Kaninchen, Meerschweinchen, Hund, Katze, Schwein, Rind und Schaf). Pflügers Arch. ges. Physiol., 268, 334 .

Beer, R., Bartels, H. and Raczkowski, H.-A. (1955). Die Sauerstoffdissoziationskurve des fetalen Blutes und der Gasaustausch in der menschlichen Placenta. ibid., 260, 306.

Bell, W. B., Cunningham, L., Jowett, M., Millet, H. and Brooks, J. (1928). The metabolism and acidity of the foetal tissues and fluids. Brit. med. J., 1, 126.

Boutourline-Young, H. and Boutourline-Young, E. (1956). Alveolar carbon dioxide levels in pregnant, parturient and lactating subjects. J. Obstet. Gynaec. Brit. Emp., 63, 509.

Darling, R. C., Smith, C. A., Asmussen, E. and Cohen, F. M. (1941). Some properties of human fetal and maternal blood. J. clin. Invest., 20, 739.
Eastman, N. J. and McLane, C. M. (1931). Foetal blood studies: lactic acid content of umbilical cord blood under various conditions. Johns Hopk. Hosp. Bull., 48, 261.

Friedman, E. A., Gray, M. J., Grynfogel, M., Hutchinson, D. L. Kelly, W. T. and Plentl, A. A. (1960). The distribution and metabolism of C14-labeled lactic acid and bicarbonate in pregnant primates. J. clin. Invest., 39, 227.

Haselhorst, G. and Stromberger, K. (1930). Über den Gasgehalt des Nabelschnurblutes vor und nach der Geburt des Kindes und über den Gasaustausch in der Plazenta. Z. Geburtsh. Gynäk. 98, 49.

Hasselbalch, K. A. (1912). Ein Beitrag zur Respirationsphysiologie der Gravidität. Skand. Arch. Physiol., 27, 1.

Hendrichs, C. H. (1957). Studies of lactic acid metabolism in pregnancy and labor. Amer. J. Obstet. Gynec., 73, 492.

James, L. S. (1959). Acidosis of the newborn and its relation to birth asphyxia. Bull. Sloane Hosp. Wom., 5, 107.

_-, Weisbrot, I. M., Prince, C. E., Holaday, D. A. and Apgar, V. (1958). The acid-base status of human infants in relation to birth asphyxia and the onset of respiration. J. Pediat., 52, 379.

Kaiser, I. H. and Goodlin, R. C. (1958). Alterations of pH, gases and haemoglobin in blood and electroly

Metcalfe, J., Romney, S., Swartwout, J. R., Pitcairn, D. M., Lethin A. N., Jr. and Barron, D. H. (1959). Uterine blood flow and A. N., Jr. and Barron, D. H. (1959). Uterine blood flow and Physiol., 197, 929.

Österlund, K. (1955). A comparative investigation of the concentration of certain electrolytes in maternal and cord blood. Ann. Paediat. Fenn., 1 (Suppl. 4), 1.

Prystowsky, H. (1957). Fetal blood studies. VII. The oxygen pressure gradient between the maternal and fetal bloods of the human in normal and abnormal pregnancy. Johns Hopk. Hosp. Bull., 101, 48.

(1958). Fetal blood studies. IX. Some aspects of oxygen transfer across the hemochorial placenta of the human in postmature pregnancy. Obstet. and Gynec., 12, 164.

(1959). Fetal blood studies. XI. The effect of prophylactic oxygen on the oxygen pressure gradient between the maternal and fetal bloods of the human in normal and abnormal pregnancy. Amer. J. Obstet. Gynec., 78, 483.

(1960). Fetomaternal gas exchange. Clin. Obstet. Gynec. 3, 286.

Hellegers, A. and Bruns, P. (1960). Fetal blood studies. XVIII. Supplementary observations on the oxygen pressure gradient between the maternal and fetal bloods of humans. Surg. Obstet. Gynec., 110, 495.

Rooth, G. and Sjöstedt, S. (1957). Haemoglobin in cord blood in normal and prolonged pregnancy. Arch. Dis. Childh., 32, 91. - and Caligara, F. (1959a). The 'in vivo' foetal oxygen dissociation curve. Biol. Neonat. (Basel), 1, 61 .

(1959b). Oxygen tension measurements in whole blood with the Clark cell. Clin. Sci., 18, 379.

(1961a) Acid-base balance of the amniotic fluid. Amer. J. Obstet. Gynec., 81, 4.

(1961b) Hydrogen concentration, carbon dioxide tension and acid base balance in blood of human umbilical cord and intervillous space of placenta. Arch. Dis. Childh., 36, 278 .

Rossier, P. H. and Hotz, M. (1953). Respiratorische Funktion und Säurebasengleichgewicht in der Schwangerschaft. Schweiz, med. Wschr., 83, 897 .

Severinghaus, J. W. and Bradley, A. F. (1958). Electrodes for blood $\mathrm{PO}_{2}$ and $\mathrm{PCO}_{2}$ determination. J. appl. Physiol., 13, 515.

Siggaard Andersen, $O$. and Engel, K. (1960). A new acid-base nomogran. An improved method for the calculation of the relevant blood acid-base data. Scand. J. clin. Lab. Invest. 12, 177 .

Sjöstedt, S. (1962). Acid base balance of the arterial blood during pregnancy, at delivery and in the puerperium. Amer.J. Obstet. Gynec. In the press.

Gynec. In the press. the blood in the umbilical cord and the intervillous space. Arch. Dis. Childh., 35, 529.

Van Slyke, D. D. and Sendroy, J., Jr. (1928). Studies of gas and electrolyte equilibria in blood; line charts for graphic calculations by Henderson-Hasselbalch equation, and for calculating plasma carbon dioxide content from whole blood content. J. biol. Chem., 79, 781 .

Vasicka, A., Quilligan, E. J., Aznar, R., Lipsitz, P. J. and Bloor, B. M. (1960). Oxygen tension in maternal and fetal blood, amniotic fluid, and cerebros vinal fluid of the mother and the baby. Amer. J. Obstet. Gynec., 79, 1041.

Vedra, B. (1959). Acidosis and anaerobiosis in full term infants. Acta paediat. (Uppsala), 48, 60.

(1960). Contribution to the pathogenesis of intra-uterine asphyxia after protracted labour. Biol. Neonat. (Basel), 2, 121.

Walker, J. (1959) Oxygen levels in the intervillous soace. In Oxygen Supply to the Human Foetus, ed. J. Walker and A. C. Turnbuli, p. 146. Blackwell, Oxford

Yllpö, A. (1916). Neugeborenen-, Hunger- und Intoxikationsacidosis in ihren Beziehungen zueinander. $Z$. Kinderheilk., 14, 268. 